\title{
Pemberian alpha lipoic acid per oral dan latihan fisik intensitas sedang menurunkan berat badan dan lemak abodminal lebih banyak daripada latihan fisik intensitas sedang saja pada tikus Wistar jantan dengan obesitas
}

\author{
${ }^{1}$ Aji B. Chandra, ${ }^{2}$ Alex Pangkahila, ${ }^{2}$ Wimpie Pangkahila
}

\author{
${ }^{1}$ Program Pascasarjana Anti-Aging Medicine \\ ${ }^{2}$ Departemen Andrologi dan Seksologi \\ Fakultas Kedokteran Universitas Udayana Denpasar \\ Email: ajibayuc@gmail.com
}

\begin{abstract}
This study was aimed to prove that oral administration of ALA and moderate physical exercise decrease body weight and abdominal fat more than moderate physical exercise only in obese male Wistar rats. This was a true experimental study with a post-test only control group design. Subjects were 30 Wistar rats (Rattus norvegicus), male, healthy, aged 4-5 months, and obese with minimum weight of $250 \mathrm{~g}$, divided into 3 groups, as follows: 1) P0, the control group with no treatment; 2) P1, given moderate physical exercise (swimming for 20 minutes/day, for 4 weeks); 3) P2, given moderate physical exercise and ALA per oral $15 \mathrm{mg} /$ day for 4 weeks. The results showed that the average body weight after 4 weeks of treatment of P0 group was $279.10 \pm 5.84 \mathrm{~g}$; of P1 group was $257.90 \pm 10.31 \mathrm{~g}$; and of P2 group was $213.90 \pm 8.92 \mathrm{~g}(P<0.01)$. The mean weight of subcutaneous abdominal fat of P0 group was $0.96 \pm 0.45 \mathrm{~g}$; of P1 group was $0.63 \pm 0.31 \mathrm{~g}$; and of P2 group was $0.40 \pm 0.23 \mathrm{~g}(P<0.01)$. Moreover, the mean weight of visceral abdominal fat of P0 group was $1.23 \pm 0.37 \mathrm{~g}$; of P1 group was $0.83 \pm 0.24 \mathrm{~g}$; and of P2 group was $0.39 \pm 0.25 \mathrm{~g}(P<0,01)$. Conclusion: Oral administration of ALA and moderate physical exercise decrease body weight, subcutaneous abdominal fat, and visceral abdominal fat more than moderate physical exercise only in obese male Wistar rats.
\end{abstract}

Keywords: alpha lipoic acid, obesity, body weight, abdominal fat

\begin{abstract}
Abstrak: Penelitian ini bertujuan untuk membuktikan bahwa pemberian ALA per oral yang dikombinasi dengan latihan fisik intensitas sedang menurunkan berat badan, lemak subkutan abdominal, dan lemak viseral abdominal lebih banyak daripada latihan fisik intensitas sedang saja pada tikus Wistar jantan dengan obesitas. Jenis penelitian ialah eksperimental murni dengan post-test only control group design. Subjek penelitian ialah 30 ekor tikus putih (Rattus norvegicus) jantan, galur Wistar, sehat, usia 4-5 bulan, dan obes dengan berat badan minimal 250 g yang terbagi menjadi tiga kelompok masing-masing berjumlah 10 ekor tikus, yaitu: P0 (kelompok kontrol), tidak mendapat perlakuan apapun; P1, kelompok perlakuan 1 yang diberikan latihan fisik intensitas sedang (renang durasi 20 menit/hari selama 4 minggu); dan P2, kelompok perlakuan 2 yang diberikan latihan fisik intensitas sedang serta ALA per oral dengan dosis $15 \mathrm{mg} /$ hari selama 4 minggu. Hasil penelitian menunjukkan bahwa rerata berat badan setelah 4

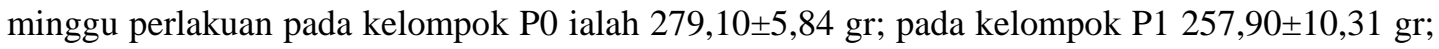
dan pada kelompok P2 213,90 $\pm 8,92$ gr $(P<0,01)$. Rerata berat lemak subkutan abdominal pada

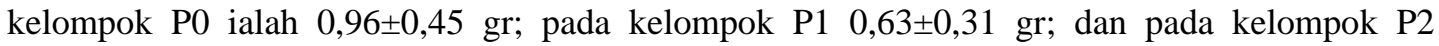
$0,40 \pm 0,23$ gr $(P<0,01)$. Selain itu, rerata berat lemak viseral abdominal pada kelompok P0 ialah $1,23 \pm 0,37$ gr; pada kelompok P1 0,83 $\pm 0,24$ gr; dan pada kelompok P2 $0,39 \pm 0,25$ gr $(P<0,01)$. Simpulan: Pemberian ALA per oral dengan latihan fisik intensitas sedang dapat menurunkan berat badan, lemak subkutan abdominal, dan lemak viseral abdominal lebih banyak daripada latihan fisik intensitas sedang saja pada tikus Wistar jantan dengan obesitas
\end{abstract}

Kata kunci: alpha lipoic acid, obesitas, berat badan, lemak abdominal 
Jumlah penyandang obesitas dan berbagai kelainan yang ditimbulkannya banyak dijumpai di seluruh dunia, termasuk Indonesia. Menurut data WHO pada tahun 2015, orang dewasa dengan kelebihan berat badan di dunia mencapai 1,9 milyar; 600 juta diantaranya dengan obesitas. Hipertensi, dislipidemia, diabetes, perlemakan hati, dan gangguan sendi merupakan kelainan penyerta yang banyak dijumpai pada penyandang obesitas. ${ }^{1,2}$ Gaya hidup tak sehat seperti diet tinggi karbohidrat dan lemak, serta pola hidup sendentari dengan aktivitas fisik sehari-hari sangat minimal, akan menyebabkan seseorang sangat rentan terhadap obesitas. ${ }^{2}$

Obesitas berhubungan erat dengan distribusi lemak tubuh. Tipe obesitas menurut pola distribusi lemak tubuh dapat dibedakan menjadi obesitas tubuh bagian atas (upper body obesity) dan obesitas tubuh bagian bawah (lower body obesity). Obesitas tubuh bagian atas merupakan dominasi penimbunan lemak tubuh di daerah trunkal. Terdapat beberapa kompartemen jaringan lemak pada trunkal, yaitu trunkal subkutan yang merupakan kompartemen paling umum, dan lemak viseral. Lemak viseral ialah lemak yang menyelimuti organ dalam tubuh. Jumlah lemak viseral berkorelasi positif dengan penyakit penyerta obesitas seperti hipertensi, diabetes, dan lainnya. ${ }^{3}$

Manajemen penurunan berat badan umumnya dilakukan dengan diet, olahraga, perubahan tingkah laku, terapi medikamentosa, atau kombinasi semuanya. ${ }^{4}$ Latihan fisik merupakan salah satu pilar untuk menurunkan berat badan. Latihan fisik merupakan aktivitas yang dilakukan seseorang untuk meningkatkan dan memelihara kebugaran tubuh. Olah raga ialah salah satu bagian dari latihan fisik yang terstruktur, terencana, dan bersifat repetitif. ${ }^{5}$ Latihan fisik sebaiknya dilakukan secara teratur dengan memperhatikan beberapa komponen yaitu jenis latihan fisik, intensitas, durasi, frekuensi, dan progresivitas latihan. ${ }^{6}$

Latihan fisik atau olahraga yang dilakukan secara teratur dengan dosis pelatihan yang tepat dapat mencapai dan mempertahankan keadaan sehat dan kebugaran fisik. Frekuensi pelatihan yang dianjurkan ialah 3 sampai 4 kali seminggu, dengan intensitas $72-87 \%$ dari denyut jantung maksimal (220-usia) dengan variasi 10 denyut per menit. Tipe pelatihan yang dianjurkan merupakan suatu kombinasi dari latihan aerobik dan pelatihan otot dalam waktu 30-60 menit, yang sebelumnya didahului oleh 15 menit pemanasan dan disusul oleh 10 menit pendinginan. Latihan fisik yang baik dilakukan pada pagi hari sampai sore hari. ${ }^{7}$ Latihan fisik yang baik ialah latihan yang dilakukan secara teratur dengan memperhatikan kemampuan tubuh. Latihan fisik atau olahraga dapat mempertahankan dan meningkatkan kesehatan tubuh, berdampak pada kinerja fisik tubuh, dan dapat mencegah penuaan dini. ${ }^{7,8}$

Selain dengan diet dan olahraga, penurunan berat badan dapat dibantu dengan mengonsumsi obat penurun berat badan. Antioksidan alpha lipoic acid (ALA) merupakan asam lemak yang mengandung komponen sulfur yang dijumpai pada setiap sel, serta merupakan kofaktor pada aktivitas mitokondria dan berperan dalam metabolisme yang membantu mengonversi glukosa menjadi energi di dalam sel. ${ }^{9}$ Beberapa penelitian yang pernah dilakukan pada tikus menunjukkan bahwa antioksidan dapat membantu proses penurunan berat badan tikus seperti dalam penelitian Kim et al. ${ }^{10}$ yang menunjukkan bahwa pemberian ALA pada tikus dapat menurunkan berat badan dengan jalan mengurangi nafsu makan dan meningkatkan pemakaian energi. ALA juga diketahui meningkatkan oksidasi asam lemak dan pembentukan mitokondria pada jaringan otot. Oksidasi asam lemak dan biogenesis mitokondria pada otot skeletal akan mengurangi lemak tubuh dan meningkatkan energy expenditure. ${ }^{11}$

Beberapa obat tablet dengan komposisi ALA murni maupun yang dikombinasi dengan antioksidan lainnya telah beredar luas di pasaran. ALA banyak digunakan di kalangan medis dari berbagai spesialisasi dengan berbagai indikasi berbeda. Dosis 
yang direkomendasi dengan efek samping minimal ialah 300-600 mg, Indikasi yang direkomendasikan antara lain untuk kasus retinopati, polineuropati akibat penyakit diabetes, sebagai antioksidan universal untuk membantu mencegah kerusakan sel, dan banyak indikasi lain yang sampai saat ini masih dalam penelitian. ${ }^{12}$

Penelitian yang dilakukan oleh Carbonelli et al. ${ }^{13}$ pada tahun 2010, menunjukkan bahwa pemberian ALA pada subjek manusia dengan obesitas memiliki efek bermakna terhadap penurunan berat badan. Efek tersebut disebabkan melalui inhibisi ALA terhadap aktivitas AMP kinase pada otak sehingga mengurangi nafsu makan serta meningkatkan jumlah pemakaian energi.

\section{METODE PENELITIAN}

Jenis penelitian ini ialah eksperimental dengan completely randomized menggunakan post-test only control group design. Subyek penelitian ialah 30 ekor tikus putih (Rattus norvegicus) jantan, galur Wistar, sehat, usia 4-5 bulan, dan obes dengan berat badan minimal 250 gr yang terbagi menjadi 3 (tiga) kelompok masing-masing berjumlah 10 ekor tikus, yaitu: kelompok kontrol (P0) tidak mendapat perlakuan apapun; kelompok perlakuan 1 (P1) yang diberikan latihan fisik intensitas sedang berupa renang di dalam ember berisi air dengan durasi 20 menit setiap hari selama 4 minggu; dan kelompok perlakuan 2 (P2) yang diberikan latihan fisik intensitas sedang berupa renang di dalam ember berisi air dengan durasi 20 menit setiap hari dan diberikan ALA per sonde satu kali sehari dengan dosis $15 \mathrm{mg}$ setiap hari selama 4 minggu.

Setelah 4 minggu pada ketiga kelompok dilakukan penimbangan berat badan dengan menggunakan timbangan Taniata kemudian diterminasi dengan cara dianestesi secara inhalasi menggunakan chloroform. Setelah itu dilakukan pembedahan, rongga abdomen dibuka, lemak subkutan abdominal yang terdapat di lapisan subkutan di daerah di antara ruas tulang punggung torakal dan ruas tulang punggung koksigeal dicari dan dipisahkan dan diukur dengan timbangan (Sartorius). Untuk lemak viseral abdominal diambil lemak yang terdapat di daerah intraperitoneal, mencakup lemak omentum dan mesenterik, diukur dengan timbangan yang sama.

\section{HASIL PENELITIAN DAN BAHASAN}

Hasil penelitian menunjukkan rerata berat badan setelah 4 minggu perlakuan kelompok kontrol (P0) ialah 279,10 $\pm 5,84$ gr; pada kelompok P1 257,90 $\pm 10,31$ gr; dan pada kelompok P2 213,90 $\pm 8,92$ gr $(P<$ 0,001). Rerata berat lemak subkutan abdominal setelah 4 minggu perlakuan kelompok kontrol (P0) ialah 1,99 $\pm 0,49$ gr; pada kelompok P1 1,46 $\pm 0,31 \mathrm{gr}$; dan pada kelompok P2 0,66 $\pm 0,24$ gr $(P<0,001)$. Rerata berat lemak viseral abdominal setelah 4 minggu perlakuan kelompok kontrol (P0) ialah 2,19 $\pm 0,76$ gr; pada kelompok P1 1,46 $\pm 0,49$ gr; dan pada kelompok P2 0,79 $\pm 0,46$ gr $(P<0,001)$. Hal ini berarti rerata berat badan, berat lemak subkutan abdominal, dan berat lemak viseral abdominal setelah 4 minggu perlakuan (posttest) antar kelompok kontrol (P0), kelompok perlakuan 1 (P1) dan kelompok perlakuan 2 (P2) berbeda sangat bermakna $(P<0,01)$. Uji lanjutan untuk mengetahui perbedaan individual antar kelompok menggunakan Least Significance Difference (LSD) test (Tabel 1).

Hasil penelitian ini sesuai dengan penelitian yang telah dilakukan sebelumnya oleh Amalia ${ }^{14}$ yang menunjukkan bahwa latihan fisik secara teratur yang dilakukan minimal 6 sampai 8 minggu dengan durasi latihan minimal 30 menit akan menyebabkan penurunan berat badan dengan rerata $1,8 \mathrm{~kg}$. Penelitian lain menunjukkan hasil yang serupa yaitu terdapat hubungan antara aktivitas fisik dengan penurunan berat badan $(P$ $=0,000) .{ }^{15}$ Perlakuan latihan fisik (renang) selama 18 minggu pada tikus menunjukkan bahwa latihan lebih banyak menyebabkan penurunan berat badan. Penurunan berat badan sebagai pengaruh dari olahraga bersamaan dengan penurunan massa lemak, 
lingkar perut, dan kadar kolesterol. ${ }^{16}$ Purwanto $^{17}$ menyatakan bahwa dalam kurun waktu 12 minggu setelah melakukan senam aerobik, persentase lemak badan menurun secara bermakna sebesar $3,42 \%$.

Tabel 1. Rerata nilai variabel antar kelompok sesudah perlakuan

\begin{tabular}{lcccccc}
\hline \multicolumn{1}{c}{ Variabel } & $\begin{array}{c}\text { Kelompok } \\
\text { subjek }\end{array}$ & N & $\begin{array}{c}\text { Rerata } \\
\text { (gram) }\end{array}$ & SB & F & P \\
\hline \multirow{3}{*}{ Berat badan } & P0 & 10 & $279,10^{\mathrm{a}}$ & 5,84 & & \\
& P1 & 10 & $257,90^{\mathrm{b}}$ & 10,31 & 150,776 & 0,000 \\
& P2 & 10 & $213,90^{\mathrm{c}}$ & 8,92 & & \\
\multirow{2}{*}{ Berat lemak subkutan } & P0 & 10 & $1,99^{\mathrm{a}}$ & 0,49 & & \\
abdominal & P1 & 10 & $1,46^{\mathrm{b}}$ & 0,31 & 34,029 & 0,000 \\
& P2 & 10 & $0,66^{\mathrm{c}}$ & 0,24 & & \\
\multirow{2}{*}{ Berat lemak viseral } & P0 & 10 & $2,19^{\mathrm{a}}$ & 0,76 & & \\
abdominal & P1 & 10 & $1,46^{\mathrm{b}}$ & 0,49 & 14,110 & 0,000 \\
& P2 & 10 & $0,79^{\mathrm{c}}$ & 0,46 & & \\
\hline
\end{tabular}

*SB = Simpangan Baku; F = F-test; $\mathrm{p}=$ signifikansi, Notasi berbeda $(\mathrm{a}, \mathrm{b}, \mathrm{c})$ menunjukkan berbeda nyata $(\mathrm{p}<0,05)$ diuji menggunakan Least Significant Difference test.

Aktivitas otot merupakan salah satu jalan untuk memindahkan lemak dari jaringan adiposa kemudian membakarnya menjadi energi di otot. ${ }^{18}$ Pelatihan fisik dapat mengurangi persentase lemak tubuh, meningkatkan massa otot, serta meningkatkan persentase jaringan non-lemak. Selain itu disebutkan pula bahwa program olahraga aerob dapat mengurangi risiko penyakit yang dihubungkan dengan obesistas. ${ }^{19}$

Aktivitas fisik memfasilitasi mobilisasi dan oksidasi lemak terutama pada jaringan adiposa viseral yang akan menyebabkan penurunan kadar lemak tubuh karena meningkatnya metabolisme basal pada selsel tubuh. ${ }^{20}$ Individu yang terlatih memiliki otot yang berkapiler dan bermitokondria lebih banyak serta dapat meningkatkan kapasitas untuk menyimpan karbohidrat dan mengoksidasi lemak. ${ }^{21}$ Peningkatan penggunaan lemak sebagai energi pada latihan endurance terjadi selama latihan submaksimal. ${ }^{22}$ Faktor lain yang berperan pada oksidasi lemak ialah proliferasi kapiler otot skelet yang meningkatkan pelepasan asam lemak ke otot, peningkatan karnitin transferase yang memudahkan transportasi asam lemak melewati membran mitokondria, dan peningkatan asam lemak pengikat protein yang mengatur transportasi asam lemak serat otot. $^{23}$

Oksidasi asam lemak menghalangi penggunaan glukosa dan glikolisis di dalam otot skelet. Kebanyakan asam lemak yang dioksidasi selama latihan dengan intensitas rendah $(25 \% \mathrm{VO} 2$ max) berasal dari asam lemak plasma. Seiring peningkatan intensitas latihan, terjadi peningkatan intramuskular triasilgliserol yang mencapai sekitar setengah total lemak yang teroksidasi. Total lemak yang teroksidasi selama latihan dengan intensitas tinggi $(>70 \%$ VO2 $\max$ ) lebih rendah dibandingkan saat latihan dengan intensitas menengah meskipun pengeluaran energi selama latihan tersebut tergolong tinggi. ${ }^{22}$ Selain pengaruh intensitas latihan, kecepatan oksidasi lemak juga dipengaruhi oleh durasi latihan yang dilakukan pada setiap intensitas. Perubahan lemak menjadi energi meningkat ketika latihan dilakukan pada periode waktu yang lama. ${ }^{24}$

Kehilangan berat badan dapat berasal dari oksidasi substrat dalam tubuh, oksidasi air, dan hilangnya air akibat pelepasan glikogen. Oksidasi substrat dalam tubuh ialah oksidasi bahan bakar metabolik (karbohidrat, lemak, dan protein) saat 
latihan. Oksidasi tersebut menghasilkan karbondioksida yang hilang saat bernapas dan menyisakan air yang terhitung sebagai berat badan. Oksidasi substrat yang terjadi kemudian menghasilkan oksidasi air. Air dapat hilang akibat pelepasan glikogen. Glikogen dalam jaringan berkaitan dengan sejumlah air dan ketika glikogen otot banyak berkurang selama latihan maka sebagian air tidak akan berikatan dengan glikogen dan menyebabkan perubahan berat badan. $^{24}$

Kim et al. ${ }^{10}$ menunjukkan bahwa pemberian alpha lipoic acid kepada tikus dapat menurunkan berat badan dengan jalan mengurangi nafsu makan dan meningkatkan pemakaian energi. Selain itu Butler et al. ${ }^{25}$ menemukan korelasi positif antara dosis ALA dengan efek penurunan berat badan. Penurunan berat badan ini kemungkinan besar disebabkan adanya efek anoreksia dari terapi ALA. ${ }^{26}$ Efek penurunan nafsu makan tersebut terutama dijumpai pada 2 minggu awal pemberian ALA dan akan menghilang secara gradual. $^{25}$ Supplementasi ALA juga diketahui dapat menurunkan berat lemak viseral. $^{27}$

Koh et al. ${ }^{28}$ melakukan penelitian terhadap 360 penyandang obesitas dan mendapatkan efek bermakna terhadap penurunan berat badan pada grup yang diberikan suplementasi ALA dengan dosis $600 \mathrm{mg}$ dan $1200 \mathrm{mg}$ dibandingkan dengan kontrol. $^{28}$ Penurunan berat badan berkorelasi positif dengan dosis ALA yang diberikan. Carbonelli et al. ${ }^{13}$ mendapatkan penurunan masa lemak tubuh, penurunan IMT dan lingkar perut pada penderita overweight yang diberikan ALA dengan dosis $800 \mathrm{mg}$ selama 4 bulan.

Selain efek terhadap penurunan berat badan, diketahui juga bahwa ALA mampu memperbaiki profil lipid, termasuk penurunan total kolesterol, trigliserida, LDL, dan meningkatkan HDL. ${ }^{29}$ Pemberian ALA dosis kisaran 50-1800 mg memberikan hasil yang bermakna dalam menurunkan kadar kolesterol total, trigliserida, dan LDL, serta meningkatkan HDL. ${ }^{30}$ Dosis ALA yang dapat memberi- kan efek perbaikan lipid darah ialah 300 mg. ${ }^{31}$

Efek penurunan berat badan dari ALA disebabkan oleh hambatan pada aktivitas AMP kinase (AMPK) pada hipotalamus. ${ }^{10}$ AMPK merupakan pengatur utama pada metabolisme glukosa dan lipid pada sel dan akan diaktivasi ketika energi seluler habis. Aktivasi AMPK pada otot skelet akan meningkatkan pengambilan glukosa. Aktivasi AMPK juga akan meningkatkan oksidasi asam lemak bebas melalui hambatan pada asetilkoenzim A
karboksilase.

AMPK yang teraktivasi akan memberikan sinyal rasa lapar, dan membuat subjek memiliki rasa ingin makan. Pemberian ALA diketahui akan menghambat aktivasi AMPK pada hipotalamus sehingga menghambat rasa lapar. ${ }^{33}$ ALA dapat menstimulasi transport glukosa dan sintesis ATP pada jaringan perifer, dan dapat menghambat aktivasi AMPK melalui peningkatan pengambilan glukosa oleh sel hipotalamus. ${ }^{10}$

ALA juga memiliki efek lipolisis. Hormone sensitif lipase (HSL) adalah lipase intrasel yang mampu menghidrolisis triasilgliserol, diasilgliserol, monoasilgliserol, dan kolesterol-ester. Enzim ini berfungsi untuk memobilisasi cadangan lemak menjadi energi. ${ }^{34}$ ALA mampu meningkatkan fosforilasi HSL yang akan memecah lemak menjadi energi dan mengurangi masa lemak subkutan maupun viseral. ${ }^{35,36}$

Walaupun mekanisme ALA dalam menurunkan berat badan dan lemak subkutan, serta efeknya dalam menurunkan profil lipid dalam darah masih belum jelas, namun ALA diketahui memiliki efek bermakna terhadap penurunan berat badan, mencegah kenaikan berat badan, mengurangi lemak subkutan dan viseral. Hasil penelitian ini juga telah membuktikan efek-efek tersebut.

\section{SIMPULAN}

Berdasarkan hasil penelitian ini dapat disimpulkan bahwa pemberian ALA secara oral dengan latihan fisik intensitas sedang 
dapat menurunkan berat badan, berat lemak subkutan abdominal, dan berat lemak viseral abdominal lebih banyak daripada dengan latihan fisik intensitas sedang saja pada tikus Wistar jantan dengan obesitas.

\section{DAFTAR PUSTAKA}

1. Wilborn C. Obesity: Prevalence, medical consequences, management, and research directions. Journal of the International Society of Sports Nutrition. 2005; 2(2):4-31.

2. WHO. Obesity and overweight. [cited 2015 Dec 12]. Available from http://www.who.int/mediacentre/facts heets/fs311/en/.

3. Burke L, Deakin V. Clinical Sports Nutrition. NSW: McGraw Hill, 2002.

4. Pestacello LS, Van Heest JL. Physical activity mediates a healthier body weight in the present of obesity. Br J Sport Med. 2003;34:86-93.

5. American College of Sports Medicine. Appropriate intervention strategies for weight loss and prevention of weight regain for adults. Med Sci Sports Exerc. 2001; 33(12): 2145-56.

6. Astrand PO, Rodahl K, Dahl HA, Stromme SB. Physiological bases of exercise. Textbook of Work Physiology (4th ed). Champaign: Human Kinetics, 2003.

7. Pangkahila A. Pelatihan fisik menurunkan proses penuaan. Naskah Lengkap Seminar Nasional Anti Aging Medicine. Denpasar: Fakultas Kedokteran Universitas Udayana, 2009.

8. Adiputra N. Kesehatan olah raga. 2008. [cited 2015 Nov 11 ]. Available from: http://www.balihesg.org/index.php?o ption $=$ com content\&task=view $\&$ id $=$ $360 \&$ itemid $=28$.

9. Islam MT. Antioxidant activities of dithiol alpha lipoic acid. J Med Science. 2009;8:254-65.

10.Kim MS, Park JY, Nam KC, Jang PG, Ryu JW, Song HS, et al. Antiobesity effects of alpha lipoic acid mediated by suppresion of hypothalamic AMP activated protein kinase. Nature. 2004; doi:10.1038./nm1061.

11.Wang Y, Li X, Guo Y, Chan L, Guan X. Alpha lipoic acid increases energy expenditure by enhancing AMPK-
PGC-1 $\alpha$ signalling in the skeletal muscle of aged mice. Metabolism. 2010; 59(7): 967-76.

12.Klein S. Is visceral fat responsible for the metabolic abnormalities associated with obesity? Implications of omentectomy. Diabetes Care. 2010; 33(7): 1693-4.

13.Carbonelli, M.G., Di Renzo, L., Bigioni, M., Di Daniele, N., De Lorenzo, A., Fusco, M.A. Alpha Lipoic Acid Supplementation : A Tool For Obesity Therapy?.Current Pharmaceutical Design. 2010; 16: 840-846.

14.Amalia A. Faktor-faktor yang mempengaruhi keberhasilan penurunan berat badan pada peserta klub kebugaran (studi kasus di klub kebugaran Indah dan Jennifer) [Skiripsi]. Semarang: Universitas Diponegoro; 2005.

15.Febrina. Hubungan antara asupan makan dan aktivitas fisik dengan penurunan berat badan wanita obes penerima farmakoterapi di klinik obesitas [Karya Tulis Ilmiah]. Semarang: Universitas Diponegoro; 2007.

16.Sudibjo P. Beberapa pertimbangan dalam pemilihan metode untuk mengestimasi lemak badan. Yogyakarta: Universitas Negeri Yogyakarta, 2009.

17.Purwanto. Dampak senam aerobik terhadap daya tahan tubuh dan penyakit. Sport Sci J. 2011;1(1):1-9.

18.Irving BA, Davis CK, Brock DW. Effect of exercise training intensity on abdominal visceral fat and body composition. Medicine and science in sports and exercise. 2008; 40(11):1863-72.

19.Sheerwood L. Fisiologi Manusia. Jakarta: EGC, 2012.

20.Dewi PK, Ieva BA, Yulianti AB. Hubungan kebugaran jasmani dan lemak tubuh pada kelompok senam dan kelompok tidak senam. Prosiding Penelitian Sivitas Akademika, Bandung: Universitas Islam Bandung, 2015.

21.Psilander $\mathbf{N}$. The effect of different exercise regimens on mitochondrial biogenesis and performance [Thesis for Doctoral Degree]. Sweden: 
Stockholm Karolinska Institutet; 2015.

22.Gropper,Sareen S, Jack L. Smith, James L. Groff. Advance Nutrition and Human Metabolism (5th ed). Wadsworth: Cengage Learning, 2009.

23.Horowitz JF, Klein S. Lipid metabolism during endurance exercise. Am J Clin Nutr. 2000;72(suppl):558S-63S

24.Achten J, Michael G, Jeunkendrup AE. Determination of the exercise intensity that elicit maximal fat oxidation. Med Sci Sports Exerc. 2002; 34(1):92-7.

25.Butler JA, Hagen TM, Moreau R. Lipoic acid improves hypertriglyceridemia by stimulating triacylglycerol clearance and down regulating liver triacylglycerol secretion. Arch Biochem Biophys. 2009;485(1):6371.

26.Seo EY, Ha AW, Kim WK. Alpha lipoic acid reduced weight gain and improved the lipid profile in rats fed with high fat diet. Nutr Res Pract. 2012;6:195-200.

27.Timmers S, de Vogel-van den Bosch J, Towler MC, Schaart G, MoonenKornips E, Mensink RP. Prevention of high fat diet-induced muscular lipid accumulation in rats by alpha lipoic acid is not mediated by AMPK activation. J Lipid Res. 2010;51:3529.

28. Koh EH, Lee WJ, Lee SA, Kim EH, Cho EH, Jeong E, et al. Effects of alphalipoic Acid on body weight in obese subjects. Am J Med. 2011;124: 85.

29.Zhang Y, Han P, Wu N, He B, Lu Y, Li S. Amelioration of lipid abnormalities by alpha-lipoic acid through antioxidative and anti-inflammatory effects. Obesity (Silver Spring). 2011; 19:1647-53.

30.Carrier B, Wen S, Zigouras S, Browne RW, Li Z, Patel MS, et al. Alphalipoic acid reduces LDL-particle number and PCSK9 concentrations in high-fat fed obese Zucker rats. PLoS One. 2014;9(3):e90863.

31.Hussein SA, Abdel-mageid AD, Abughazalla AM. Biochemical study on the effect of alpha-lipoic acid on lipid metabolism of rats fed high fat diet. Benha Vet Med J. 2015;28(1):109-19.

32.Hayashi T. Metabolic stress and altered glucose transport: activation of AMPactivated protein kinase as a unifying coupling mechanism. Diabetes. 2000; 49: 527-31.

33.Kola B. Role of AMP-activated protein kinase in the control of appetite. J Neuroendocrinol. 2008;20(7):942-51.

34.Kolehmainen M, Vidal H, Ohisalo JJ, Pirinen E, Alhava E, Uusitupa MI. Hormone sensitive lipase expression and adipose tissue metabolism show gender difference in obese subjects after weight loss. Int $\mathbf{J}$ Obes Relat Metab Disord. 2002;26(1):6-16.

35. Watt MJ, Holmes AG, Pinnamaneni SK, Garnham AP, Steinberg GR, Kemp BE, et al. Regulation of HSL serine phosphorylation in skeletal muscle and adipose tissue. Am J Physiol Endocrinol Metab. 2006;290(3): E500-8. Epub 2005 Sep 27.

36.Fernández-Galilea $M$, Pérez-Matute $P$, Prieto-Hontoria PL, Martinez JA, Moreno-Aliaga MJ. Effects of lipoic acid on lipolysis in 3T3-L1 adipocytes. J Lipid Res. 2012;53(11): 2296-306. Doi: 10.1194/jlr.M027086. Epub 2012 Aug 31. 